\title{
Distribution of Dopamine in 35 Subregions of the Rat Caudate-Putamen: A High Performance Liquid Chromatography with Electrochemical Detection Analysis
}

\author{
THÉRÈSE DI PAOLO, MICHEL DAIGLE and ANDRÉ DUPONT
}

SUMMARY: Topographical variations in the endogenous content of dopamine were studied in the rat caudate-putamen. For this purpose, a high performance liquid chromatography with electrochemical detection procedure for the determination of norepinephrine, epinephrine and dopamine in nervous tissue samples is described. Tissue preparation required only homogenization in acidic solution and centrifugation prior to application to the chromatograph.

RESUMÉ: Les variations topographiques du contenu endogène de dopamine ont été étudiées dans le caudé-putamen de rat. Pour cette étude, un dosage par chromatographie liquide à haute performance avec détection électrochimique de la norépinéphrine, de l'épinéphrine et de la dopamine dans les tissus nerveux a été mis au point. La préparation du tissu requiert seulement une homogénisation en solution acide et une centrifugation avant l'injection
Detection limits in the low picogram range were found for the catecholamines separated. This assay was used in combination with a micropunch dissection technique. The performance of this analytical technique is illustrated by the detailed mapping of dopamine content in 35 subregions of the rat caudate-putamen. The distribution of dopamine varies along the major axis of the nucleus.

sur le chromatographe. Des limites de détection au niveau du picogramme ont été obtenues pour les trois catécholamines analysées. Ce dosage a été utilisé en combinaison avec une technique de microdissection. L'application de cette technique analytique est illustrée par l'analyse détaillée du contenu en dopamine dans 35 régions du caudé-putamen de rat. La distribution de la dopamine varie le long $d u$ grand axe de ce noyau.
From the Department of Molecular Endocrinology, Le Centre Hospitalier de l'Université Laval, Quebec G1 V 4G2, Canada.

Requests for Reprints to: Dr. Thérèse Di Paolo, Department of Molecular Endocrinology, Le Centre Hospitalier de I'Université Laval, Quebec, P.Q., Canada GIV 4G2.
The distribution of catecholamines has been widely studied using different techniques in both laboratory animals (Coyle and Henry, 1973; Felice et al., 1978; Fuxe et al., 1977; Hökfelt, 1968; Jacobovitz and Palkovits, 1974; Van Der Gugten et al., 1976) and man (FAHN et al., 1971; Mefford et al., 1978). These studies have been useful in the understanding of the clinical manifestations of both psychiatric (Usdin et al., 1979) and movement disorders (Fahn et al., 1971; Mattsson et al., 1974). Much research effort has been directed toward the development of animal models of human disorders including models of depression (Porsalt et al., 1978), hypertension (Chalmers, 1975), movement disorders (Ungerstedt, 1968) and sleep disorders (Delashaw et al., 1979). These models while not identical to the corresponding human visorders have yielded relevant biochemical, pharmacological and behavioral information which has been found to be applicable to the treatment of these disorders.

The striatum which plays an important role in sensory-motor integration (Usdin et al., 1978) was thought until recently to contain an homogenous dopaminergic innervation. With the advent of highly sensitive dopamine assays (Koslow et al., 1974; Saraswat et al., 1981; Tassin et al., 1976) and the elaboration of microdissection techniques (Palkovits, 1973), the striatum was reinvestigated and results suggest that the extent of dopaminergic innervation is heterogenous within this structure (Koslow et al., 1976). However, there are discrepancies in the topographical distributions of dopamine in the caudate putamen reported by different investigators, the age of the 
rats studied being a possible variable (Tassin et al., 1976). In the present study, we have developed a high pressure liquid chromatographic with electrochemical detection assay (LCEC) of catecholamines and applied it to the topographical distribution of dopamine in the rat caudate-putamen.

Several LCEC procedures have been reported for the determination of catecholamines in brain tissue (Sasa and Blank, 1979; Moyer and Jiang, 1978; Felice, Felice and Kissinger, 1978; Mefford, Gilberg and Barchas, 1980; Crombeen, Kraak and Poppe, 1978; Wagner, Palfreyman and Zraika, 1979; Freed and Asmus, 1979). The high degree of selectivity and sensitivity makes the LCEC technique directly applicable to extremely small samples. We have found that catecholamines can be determined in rat brain by a direct injection of the supernatant obtained after homogenization and centrifugation of the tissue. The assay reported here was designed for regional brain mapping in combination with the micro-punch dissection technique developed by Palkovits (1973). Its performance is illustrated by the detailed mapping of the dopamine content in 35 sub-regions of the rat caudate-putamen.

\section{MATERIALS AND METHODS Apparatus}

The LCEC system consisted of a Spectra-Physics 8000 liquid chromatograph with a stainless steel chromegabond $\mathrm{MC}-18$ (octadecylbonded on silica, C18,10 $\mu \mathrm{m}, 4.6 \mathrm{x}$ $300 \mathrm{~mm}$ column; ES Industries, Marlton, New Jersey, U.S.A.) and a pre-column packed with $\mathrm{C}_{18}$ particles. The pre-column packing was changed every 3-4 months. A model LC-4 electrochemical detector was used with a CP-0 carbon paste electrode (Bioanalytical Systems, West Lafayette, Indiana, U.S.A.). The potential was set at $0.65 \mathrm{~V}$ with respect to an $\mathrm{Ag}+/ \mathrm{AgCl}$ reference electrode.

\section{Animals}

Adult female Sprague-Dawley rats (200-250 g body weight) housed in temperature, humidity and light (lights on at $06.00 \mathrm{~h}$ off at $18.00 \mathrm{~h}$ ) controlled quarters were bilaterally ovariecto- mized and were allowed food and water ad libitum. Animals were sacrificed 2 weeks after ovariectomy by decapitation between 8:00-10:00 a.m.

\section{Reagents}

The eluting solvent for the LCEC system consisted of a $0.1 \mathrm{M} \mathrm{NaH} \mathrm{NO}_{4}$, $0.1 \mathrm{mM}$ EDTA, pH 5.5, containing 5.0 $\mathrm{mM}$ sodium heptanesulfonate and methanol (0-10\%). The mobile phase was delivered at a flow rate of 2.0 $\mathrm{ml} / \mathrm{min}$. Water used was distilled and deionized. The buffer was filtered through a $0.45 \mu \mathrm{m}$ Millipore filter and degassed with helium. Dopamine hydrochloride (DA), epinephrine bitartrate $(E)$, norepinephrine hydrochloride (NE) and 3,4-dihydroxybenzylamine hydrobromide (DHBA, an internal standard) of the highest purity were obtained from commercial sources. All concentrations of the biogenic amines are expressed as the free base. Standard solutions were prepared in $0.1 \mathrm{M} \mathrm{HClO}_{4}$ and stored at $90^{\circ} \mathrm{C}$; fresh solutions were prepared every 2 or 3 days.

\section{Procedure}

Sample preparation - The brains were removed rapidly (within $1 \mathrm{~min}$ of decapitation) and frozen with dry ice. Serial $300, \mu \mathrm{m}$ coronal sections were cut in the stereotaxic plane of Konig and Klippel (1967) in a microtome at $-10^{\circ} \mathrm{C}$ as described by Palkovits (1973). Samples were punched from sections with small stainless steel needles (inside diameters, $1 \mathrm{~mm}$ ) and homogenized using a microhomogenizer in $100 \mu \mathrm{l}$ ice cold $0.1 \mathrm{M} \mathrm{HClO}_{4}$ for extraction of catecholamines. After centrifugation at $10,000 \times \mathrm{g}$ for $20 \mathrm{~min}$ at $4^{\circ} \mathrm{C}$, the supernatants were stored at $-90^{\circ} \mathrm{C}$ in small polyethylene tubes until assayed. Each pellet was dissolved in $100 \mu \mathrm{l}$ of $1 \mathrm{M} \mathrm{NaOH}$ for determination of protein content by the method of Lowry et al., (1951). When ready for analysis, the supernatant samples were thawed, kept on ice-water at $4^{\circ} \mathrm{C}$ in the dark and aliquots of 10 to $75 \mu \mathrm{l}$ were injected into the LCEC system.

\section{Calculations}

The concentrations of catecholamines in brain tissue were determined by measuring peak heights and comparing them with standards which were run through the whole procedure. No deviation from linearity was detected over the range of samples analyzed, $0.02 \mathrm{ng}$ to $5 \mathrm{ng}$ for NE, E and DA. The concentrations ( $\mathrm{ng} /$ punch or $\mathrm{ng} / \mathrm{mg}$ of protein) were calculated knowing the response of the standards and the number of punches dissected or the protein content of the tissue assayed. Statistical significance was measured according to the multiple-range test of Duncan-Kramer (Kramer, 1956).

\section{RESULTS}

The optimized isocratic conditions developed by Moyer and Jiang (1978) were first investigated for the analysis of catecholamines. These authors used an isocratic aqueous mobile phase (0.1 $\mathrm{M} \mathrm{NaH}_{2} \mathrm{PO}_{4}, 0.1 \mathrm{mM}$ EDTA, 5.0 $\mathrm{mM}$ heptanesulfonate, $\mathrm{pH} 5.5$, flow rate $2.0 \mathrm{ml} / \mathrm{min}$ ) eluting over a bonded octadecylsilane ( $\mu$ 'Bondapak $\left.\mathrm{C}_{18}\right)$ solid-phase with amperometric detection of the eluate. Using this buffer system with our column, the catecholamines were retained strongly: norepinephrine eluting at $6.5 \mathrm{~min}$, epinephrine at $12.2 \mathrm{~min}$, DHBA at $15.5 \mathrm{~min}$ and dopamine at $27 \mathrm{~min}$, while the metabolites eluted more rapidly: 3,4-dihydroxyphenylacetic acid $(2.5 \mathrm{~min}), 3,4-$ dihydroxyphenylglycol $(2.8 \mathrm{~min})$ and homovanillic acid $(5.0 \mathrm{~min})$ as well as the precursor dihydroxyphenylalanine (3.0 min).

To accelerate this chromatography (10 $\mathrm{min}$ or less) for routine assay of catecholamines, $10 \%$ methanol was added to the buffer. Under these conditions, norepinephrine elutes at 3.6 minutes, epinephrine at $4.3 \mathrm{~min}$, DHBA at $5.2 \mathrm{~min}$ and dopamine at 7.0 min while the metabolites are not separated from the solvent front. With these chromatographic conditions, Fig. 1 shows typical chromatograms of standards and brain extracts. Tissue samples were homogenized in $100 \mu$ l of $0.1 \mathrm{M} \mathrm{HClO}_{4}$ and centrifuged. $40 \mu \mathrm{l}$ (striatum) or $50 \mu \mathrm{l}$ (median eminence) of the supernatant was injected on the LCEC system. Fig. 1 shows striatal tissue containing $3.0 \mathrm{ng} / \mathrm{mg}$ of protein of $\mathrm{NE}$ and $120.0 \mathrm{ng} / \mathrm{mg}$ of protein of DA while the median eminence content was 


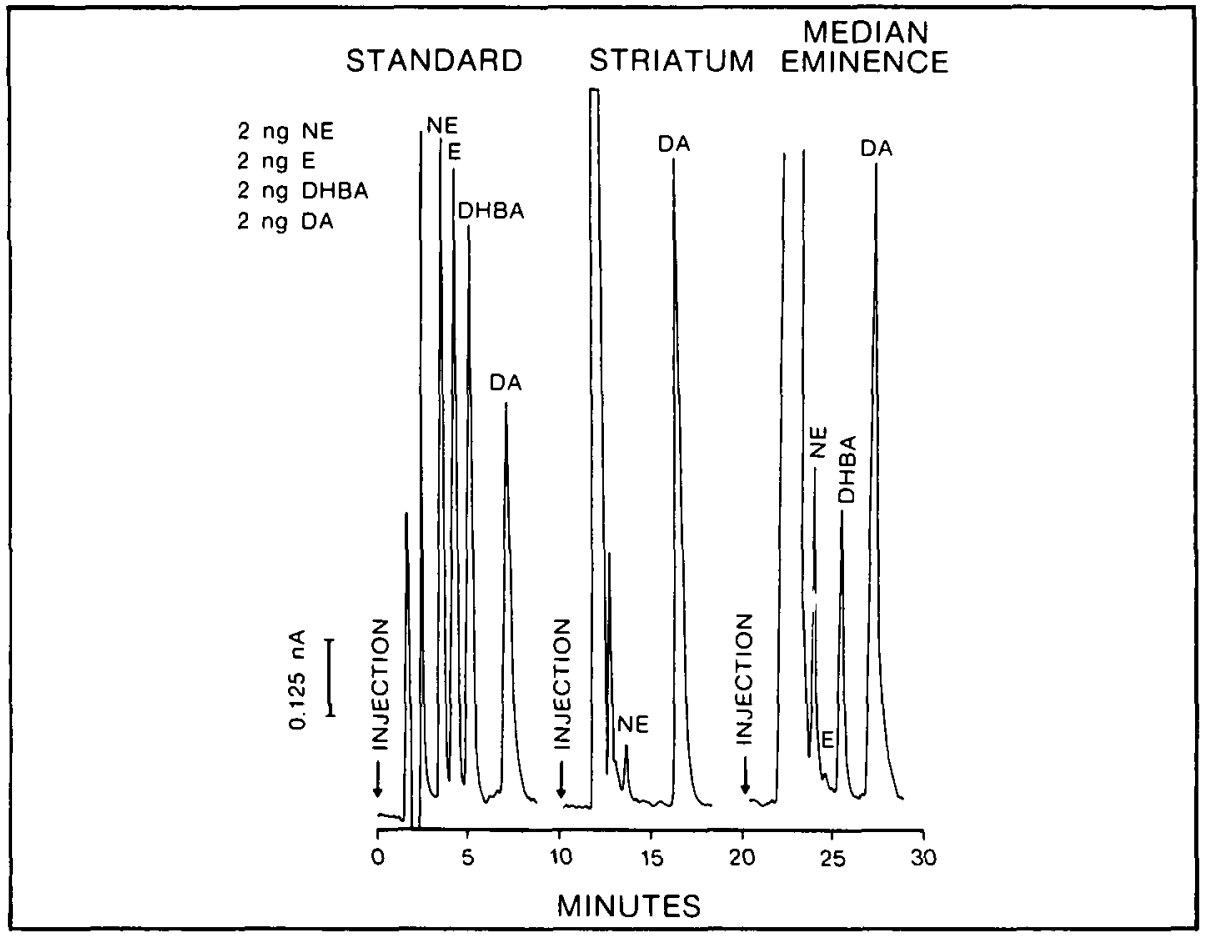

Figure I - LCEC chromatograms after injection of $2 \mathrm{ng}$ of authentic norepinephrine (NE), epinephrine (E), dihydroxybenzylamine (DHBA) and dopamine (DA) or brain extracts. Rat striatal tissue (in the A 9000 plane) contains $3.0 \mathrm{ng} / \mathrm{mg}$ of protein of $\mathrm{NE}$ and $120 \mathrm{ng} / \mathrm{mg}$ of protein of dopamine while the median eminence contains $20.5 \mathrm{ng} / \mathrm{mg}$ of protein of NE, $1.5 \mathrm{ng} / \mathrm{mg}$ of protein of $E$ and $95 \mathrm{ng} / \mathrm{mg}$ of protein of DA.
NE: $20.5 \mathrm{ng} / \mathrm{mg}$ of protein, E: 1.5 $\mathrm{ng} / \mathrm{mg}$ of protein, DA: $95 \mathrm{ng} / \mathrm{mg}$ of protein and the internal standard DHBA (1 ng) was $99 \%$ recovered. Routine detection limits were $20 \mathrm{pg}$ for $\mathrm{NE}$ and $\mathrm{E}$ and $50 \mathrm{pg}$ for DA.0.5, 1, and 2 ng of the standards NE, E and DA were chromatographed $(n=25)$ and coefficients of variations of $3 \%$ or less were obtained.

The performance of this assay is illustrated in Figures 2 and 3. The dopamine content per punch of striatal tissue was investigated throughout this brain structure. The results shown are the means for three rats with two determinations per rat (bilateral dissection). Standard errors of the mean, reflecting the dissection, individual differences between rats and HPLC errors, are, on the average, $10 \%$ for dopamine.

\section{DISCUSSION}

We have described the separation of norepinephrine, epinephrine and dopamine using HPLC with electrochemical detection and the combination of this assay with a precise

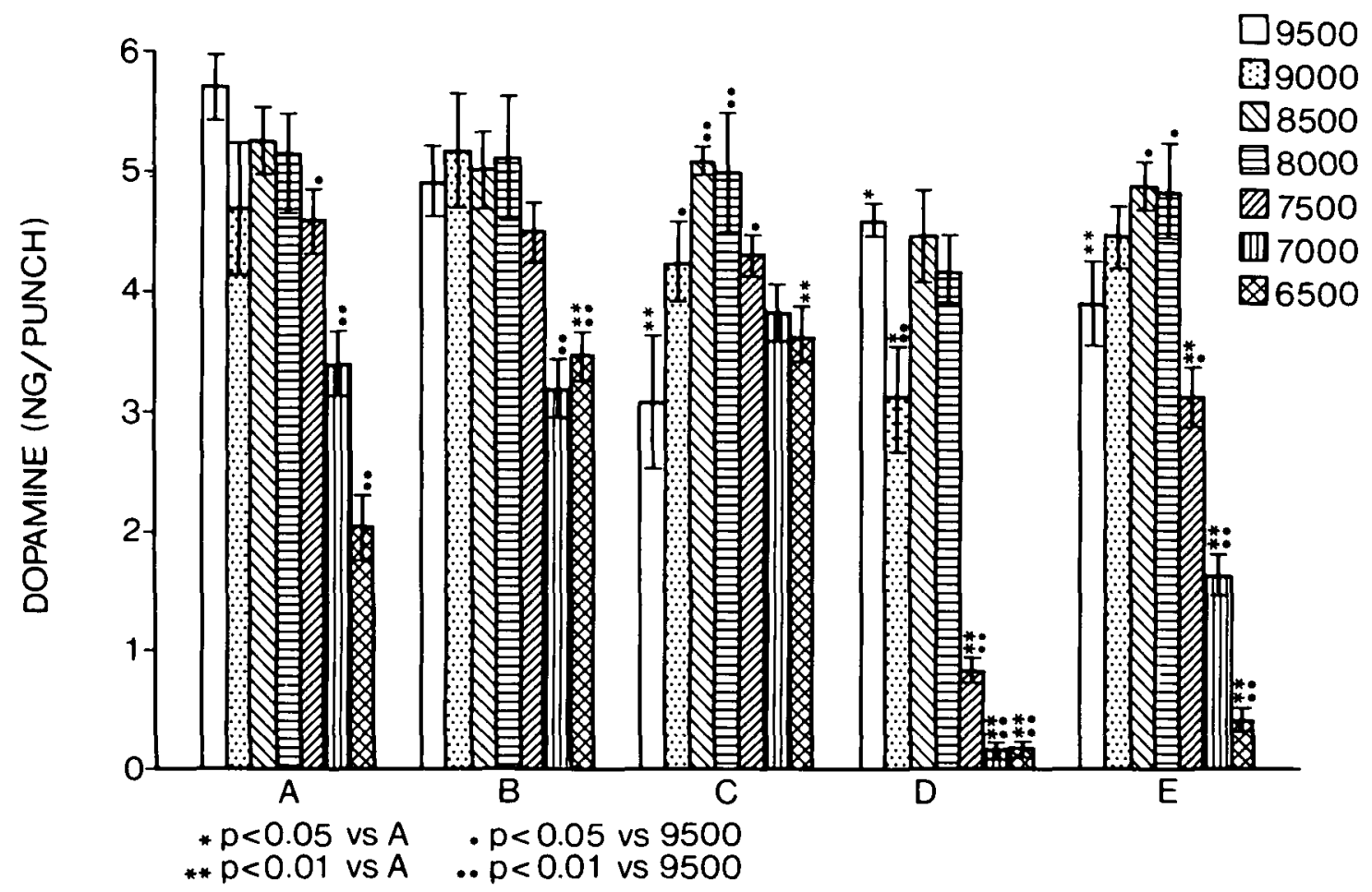

Figure 2 - Dopamine concentrations in the 35 subregions of the rat caudate-putamen. The dissection was done bilaterally and the punch analyzed individually. Three rats were dissected and the dopamine results shown are the average \pm SEM of 6 determinations. Comparisons were made from the anterior to posterior regions $\left(\bullet p<0.05\right.$ or $\bullet^{*} p<0.01$ vs 9500$)$ as well as within the five regions assayed in a slice $\left({ }^{\bullet} p<0.05\right.$ or $\bullet^{\circ} p<0.01$ vs $\left.A\right)$. Positions of the analyzed punched out areas are shown in Fig. 3. 

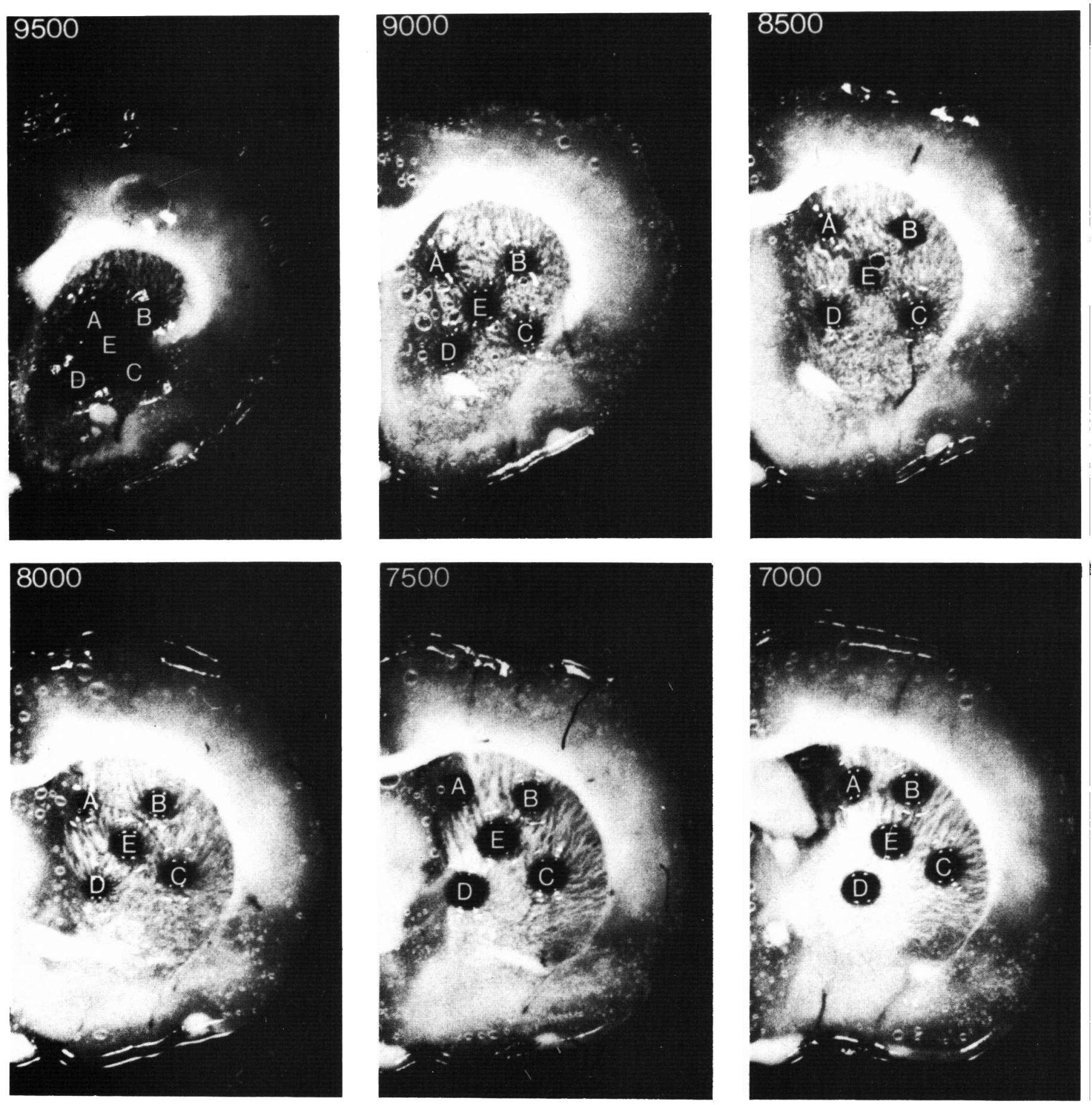

Figure 3 - Rat brain slices from 9500 to 6500 with black holes labelled A to E showing the position of the punched out areas analyzed.

microdissection technique. The method described is simple, requiring minimal sample handling and preparation. The separation of compounds is rapid with good resolution, permitting the measurement of femtomole quantities of all three catecholamines in less than 10 min with a single column injection. As shown in Fig. 1, recovery of the in- ternal standard is almost complete and, in most routine studies, it was not included. Because this method is simple and rapid, 40 or more samples can be analyzed in a day. This assay could also be automated and the use of an automatic sample changer would substantially increase the working capacity. A drawback of the direct injection of biological material is a shortened lifetime of the column, particularly the column top (Westerling, Carlquist and Theodorsen, 1979). However, with the use of a pre-column, we have found our columns to be satisfactory for more than 2,000 injections.

The rapidity and simplicity of the assay combined with the precise micro- 


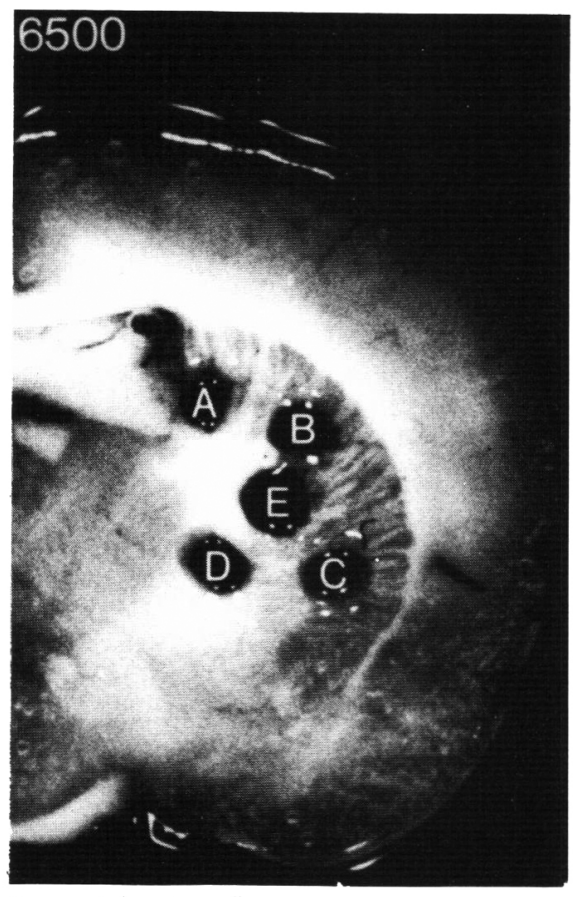

Figure 3 (continued)

Figure 3 (continued)

punch dissection technique enables a complete routine study of drug effects in all the major catecholamine regions of the brain.

The median eminence and striatum catecholamines levels shown in Fig. 1 are in good agreement with the values reported using radioenzymatic assays (Crowley, O'Donohue and Jacobowitz, 1978; Crowley et al., 1978; Van Der Gugten et al., 1976).

The distribution of dopamine reported here shows a high concentration of dopamine rather evenly distributed (in regions $\mathrm{A}, \mathrm{B}$ and $\mathrm{D}$ ) or increasing (in regions $C$ and $E$ ) from the 9500 to 8000 serial sections of the anterior striatum. The dopamine content then decreases from the 8000 to 6500 levels in the five regions $A$ to $E$ analyzed. This is in agreement with the high concentration of dopaminergic neuronal terminals in this area and with the distribution of dopamine reported by Tassin et al. (1976) by a radioenzymatic assay of dopamine. Variations in the dopamine content between regions $A$ to $\mathrm{E}$ are observed from the planes 9500 to 8000 , the regions A showing higher concentrations. The differences in dopamine observed in the 7500 to 6500 plane between regions $A$ to $E$ are even greater, the globus pallidus regions $D$ and $E$ being much lower than the striatal punches A, B and C. This is in agreement with the high dopaminergic innervation of the striatal region as compared to the globus pallidus. The distribution of striatal dopamine is also in agreement with the histochemical fluorescence observations of Fuxe et al. (1977) who reported that the caput of the neostriatum gave high fluorescence intensity and the dorsolateral middle part high intensity while the medioventral part gave only medium intensity and a weak-medium intensity was found in the entire caudal part. This heterogenous striatal dopamine distribution is also compatible with the known complex innervation of the neostriatum (Fuxe et al., 1977). The observation of higher concentrations of dopamine in the rostral part of the caudate nucleus as compared to the caudal regions agrees with ultrastructural studies (Hökfelt, 1968; Hökfelt and Ungerstedt, 1969, 1973) indicating such a gradient of dopamine boutons.

A rostro-caudal decrease in striatal dopamine levels has also been reported for the 5 substriatal regions assayed using LCEC by Saraswat et al. (1981). Tassin et al. (1976) observed a progressive decrease in dorsal, mediolateral and ventral areas of the striatum from 9500 to $5500 \mu \mathrm{m}$ using a radioenzymatic assay of dopamine.

By contrast, using a $1.2 \mathrm{~mm}$ diameter punch in central area of the caudate-putamen sections Koslow et al. (1974) observed a bimodal distribution of dopamine. In our study, using five dorso-caudal sub-regions $1.0 \mathrm{~mm}$ in diameter, no bimodal distribution was observed; however in regions $C$, $\mathrm{D}, \mathrm{E}$ a normal distribution with a maximum at about $8500 \mu \mathrm{m}$ correlating well with the normal distribution of acetylcholine (Koslow et al., 1974) was observed. Similar distributions in the rat caudate-putamen of dopaminergic and cholinergic fibers have also been observed by histofluorescence and acetylcholinesterase histochemical methods (Jacobowitz and Palkovits, 1974). Furthermore, an inhibitory striatal dopaminergic action on cholinergic function is well known (Guyenet et al., 1975; Stadler et al., 1973). These observations are relevant to the understanding of Parkinson's disease where a reduction in the number of dopamine afferents can be assumed to shift the balance of the innervation of the striatum in the direction of acethylcholine fibers. This colocalization has provided the rationale for the use of anticholinergic drugs and L-DOPA in the treatment of Parkinsonian patients. The differences of dopamine distributions between our results and those of Koslow et al. (1974) are unlikely due to differences in the dopamine assays. Differences in the strain and age of the animals could be involved in this effect. Indeed, Koslow et al. (1974) used much younger animals $(150 \mathrm{~g})$ than those of Tassin et al. (1976) $(400 \mathrm{~g})$, while we have used rats weighing 200-250 g. These possible age variations may have important implications since a rostrocaudal variation in the distribution of tyrosine hydroxylase in the human caudateputamen as a function of age has also been reported (McGeer et al, 1971). Since there is no clear anatomical delineation between the caudate-putamen complex, the nucleus accumbens and the globus pallidus in the rat, slight differences could occur depending on the exact localization of the punch, particularly in the rostral and caudal part of the structure. Thus, in our study, we have analyzed 5 subregions in each of the serial sections while others have assayed one (Koslow et al., 1974; Saraswat et al., 1981) or three (Tassin et al., 1976).

Rat striatal concentrations of dopamine have been shown to fluctuate during the estrus cycle (Crowley et al., 1978) and to be decreased after chronic estrogen treatment (Dupont et al., 1981). Recently, Malouin and Bédard (1983) have shown that a thyrotropinreleasing hormone (TRH) injection in specific areas of the caudate can induce head turning in the rat, thus suggesting a localization of the hormone-catecholamines interactions in this nucleus. The dopaminergic heterogenity of the caudate nucleus has been well demonstrated with electrophysiological, biochemical, pharmacological, functional and clinical data (Cools, 1973; Cools and Van Rossum, 1976; Cools et al., 1976). The depletion of human neostriatal dopamine in Parkinson's disease is well known and Fahn et al. (1971) have reported an un- 
even decline of dopamine in this structure.

As described here, the fine anatomical distribution of dopaminergic terminals within the striatum can be studied by measuring the amine content in punched microdiscs. This very sensitive method has revealed an uneven distribution of striatal dopamine and shows that proper sampling is essential to determine alterations in amine concentrations. This technique will thus be useful to evaluate dopamine regional variations after drug treatments, and in different diseases and hormonal states.

\section{REFERENCES}

CHALMERS, J.P. (1975). Brain amines and models of experimental hypertension. Circulat. Res. 36, 469-480.

COOLS, A.R. (1973). Chemical and electrical stimulation of the caudate nucleus in freelymoving cats: the role of dopamine. Brain Res., 58, 437-451.

COOLS, A.R., STRUYKER BOUDIER, H.A.J. and VAN ROSSUM, J.M. (1976). Dopamine receptors: selective agonists and antagonists of functionally distinct types within the feline brain. Eur. J. Pharmacol. 37, 283-293.

COOLS, A.R. and VAN ROSSUM, J.M (1976). Excitation-mediating and inhibitionmediating dopamine receptors: a new concept towards a better understanding of electrophysiological, biochemical, pharmacological, functional and clinical data. Psychopharmacologia (Berl.), 45, 243-254.

COYLE, J.T. and HENRY, D. (1973). Catecholamines in fetal and newborn rat brain. $J$. Neurochem., 21, 61-67.

CROMBEEN, J.P., KRAAK, J.C. and POPPE, H. (1978). Reversed-phase systems for the analysis of catecholamines and related compounds by high-performance liquid chromatography. J. Chromat., 167, 219230.

CROWLEY, W.R., O'DONOHUE, T.L. and JACOBOWITZ, D.M. (1978). Changes in catecholamine content in discrete brain nuclei during the estrous cycle of the rat. Brain Res., 147, 315-326.

CROWLEY, W.R., O'DONOHUE, T.L., WACHSLICHT, H. and JACOBOWITZ, D.M. (1978). Effects of estrogen and progesterone on plasma gonadotropins and on catecholamine levels and turnover in discrete brain regions of ovariectomized rats. Brain Res., 154, 345-357.
DELASHAW, J.B. JR., FOUTZ, A.S., GUILLEMINAULT, C. and DEMENT, W.C. (1979). Cholinergic mechanisms and cataplexy in dogs. Exp. Neurol. 66, 745-757.

DUPONT, A., DI PAOLO, T., GAGNE, B. and BARDEN, N. (1981). Effects of chronic estrogen treatment on dopamine levels and turnover in discrete brain nuclei of ovariectomized rats. Neurosci. Lett. 22, 69-74.

FAHN, S., LIBSCH, L.R. and CUTLER, R.W (1971). Monoamines in the human neostriatum: topographic distribution in normals and in Parkinson's disease and their role in akinesia, rigidity chorea and tremor. J. Neurol. Sci. 14, 427-455.

FELICE, L.J., FELICE, J.D. and KISSINGER, P.T. (1978). Determination of catecholamines in rat brain parts by reversephase ion-pair liquid chromatography. J. Neurochem., 31, 1461-1465.

FREED, C.R. and ASMUS, P.A. (1979). Brain tissue and plasma assay of L-Dopa and methyldopa metabolites by high performance liquid chromatography with electrochemical detection. J. Neurochem., 32, 163 168

FUXE, K., HÖKFELT, T., OLSON, L. and UNGERSTEDT, U. (1977) Central monoaminergic pathways with emphasis on their relation to the so called 'extrapyramidal motor system'. Pharmac. Ther. B, 3, 169210.

GUYENET, P.G., AGID, Y., JAVOY, F. BEAUJOVAN, J.C., ROSSIER, J. and GLOWINSKI, J. (1975) Effects of dopamine receptor agonists and antagonists on the activity of the neostriatal cholinergic system. Brain Res., 84, 227-244.

HÖKFELT, T. (1968). In vitro studies on central and peripheral monoamine neurons at the ultrastructural level. Z. Zellforsch, 91, 1-74.

HÖKFELT, T., JOHANSSON, O., FUXE, K., GOLDSTEIN, M. and PARK, D. (1977). Immunohistochemical studies on the localization and distribution of monoamine neuron systems in the rat brain. II. Tyrosine hydroxylase in the telencephalon, Med. Biol., 55, 21-40.

HÖKFELT, T. and UNGERSTEDT, U. (1969). Electron and fluorescence microscopical studies on the nucleus caudatus putamen of the rat after unilateral lesions of ascending nigro-neostriatal dopamine neurons. Acta Physiol. Scand. 76, 415-426.

HÖKFELT, T. and UNGERSTEDT, U. (1973). Specificity of 6-hydroxydopamine induced degeneration of central monoamine neurones: An electron and fluorescence microscopic study with special reference to intracerebral injection on the nigrostriatal dopamine system. Brain Res. 60, 269-297.
JACOBOWITZ, D.M. and PALKOVITS, M. (1974). Topographic atlas of catecholamine and acetylcholinesterase-containing neurons in the rat brain. J. Comp. Neur. 157, 13-28.

KRAMER, C.Y. (1956). Extension of multiplerange tests to group means with unequal numbers of replications. Biometrics, 12 , 307-310.

KONIG, J.R.F. and KLIPPEL, R.A. (1967). The rat brain: a stereotaxic atlas of the forebrain and lower parts of the brain stem, Krieger Publishers, Huntingdon, New York.

KOSLOW, S.H., RACAGNI, G. and COSTA E. (1974). Mass-fragmentographic measurement of norepinephrine, dopamine, serotonin and acetylcholine in seven discrete brain nuclei of the rat tel-diencephalon. Neuropharmacol., 13, 1123-1130.

LOWRY, O.H., ROSEBROUGH, N.J., FARR, A.L. and RANDALL, R.J. (1951). Protein measurement with the Folin phenol reagent. J. Biol. Chem., 193, 265-275.

MALOIN, F. and BÉDARD, P.J. Head turning induced by unilateral intracaudate thyrotropin-releasing hormone (TRH) injection in the cat, Eur. J. Pharmacol. (in press).

MATTSSON, B., GOTTFRIES, C.-G., ROOS, B.-E. and WINBALD, B. (1974). Huntingtons chorea: pathology and brain amines, Acta Psychiat. Scand., Suppl. 255, 269-277.

McGEER, E.G., McGEER, P.L. and WADA, J.A. (1971). Distribution of tyrosine hydroxylase in human and animal brain. $J$. Neurochem., 18, 1647-1658.

MEFFORD, I.N., GILBERG, M. and BARCHAS, J.D. (1980). Simultaneous determination of catecholamines and unconjugated 3,4-dihydroxyphenylacetic acid in brain tissue by ion-pairing reverse-phase highperformance liquid chromatography with electrochemical detection. Anal. Biochem., $104,469-472$.

MEFFORD, I., OKE, A., KELLER, R., ADAMS, R.N. and JONSSON, G. (1978). Epinephrine distribution in human brain. Neurosci. Lett. 5, 141-145.

MOYER, T.P. and JIANG, N.S. (1978). Optimized isocratic conditions for analysis of catecholamines by high performance reversed-phase paired-ion chromatography with a mperometric detection. J. Chromatogr., $153,365-372$.

PALKOVITS, M. (1973). Isolated removal of hypothalamic or other brain nuclei of the rat. Brain Res., 59, 449.450.

PORSOLT, R.D., ANTON, G., BLAVET, N. and JALFRE, M. (1978). Behavioral dispair in rats, a new model sensitive to antidepressant treatments. Eur. J. Pharmacol. 47, 379-391. 
SARASWAT, L.D., HOLDINESS, M.R., JUSTICE, J.B., SALAMONE, J.D. and NEILL, D.B. (1981). Determination of dopamine, homovanillic acid and 3,4dihydroxyphenylacetic acid in rat brain striatum by high performance liquid chromatography with electrochemical detection. J. Chromat., 222, 353-362.

SASA, S. and BLANK, C.L. (1979). Simultaneous determination of norepinephrine, dopamine and serotonin in brain tissue by high pressure liquid chromatography with electrochemical detection. Anal. Chim. Acta, 104, 29-45.

STADLER, H., LLOYD, K.G., GADEACIRIA, M. and BARTHOLINI, G. (1973). Enhanced striatal ACh release by chlorpromazine and its reversal by apomorphine. Brain Res. 55, 476-480.
TASSIN, J.P., CHERAMY, A., BLANC, G., THIERRY, A.M. and GLOWINSKI, J. (1976). Topographical distribution of dopaminergic innervation and of dopaminergic receptors in the rat striatum. I. Microestimation of $\left[{ }^{3} \mathrm{H}\right]$ dopamine uptake and dopamine content in microdiscs. Brain Res., 107, 291-301.

UNGERSTEDT, U. (1968). 6-hydroxydopamine-induced degeneration of central monoamine neurons. Europ. J. Pharmacol., 5, 107-110.

USDIN, E., KOPIN, I.J. and BARCHAS, J. (1979). Catecholamines: basic and clinical frontiers. Pergamon Press, New York.

VAN DER GUGTEN, J., PALKOVITS, M., WIJNEN, H.L.J.M. and VERSTEEG, D.H.G. (1976). Regional distribution of adrenaline in rat brain. Brain Res., 107, 171175.
WAGNER, J., PALFREYMAN, M. and ZRAIKA, M. (1979). Determination of DOPA, dopamine, DOPAC, epinephrine, norepinephrine, $\alpha$-monofluoromethyldopa and $\alpha$-difluoromethyldopa in various tissues of mice and rats using reversed-phase ionpair liquid chromatography with electrochemical detection. J. Chromatogr., 164, 41 54.

WESTERLUND, D., CARLQVIST, J. and THEODORSEN, A. (1979). Analysis of penicillins in biological material by reversed phase liquid chromatography and postcolumn derivatization. Acta Pharm. Suecica, 16, 187-214. 